\title{
隠岐諸島における舟小屋の分布状況と立地・構法の特性 A STUDY ON EXISTENCE SITUATION AND WOODEN CONSTRUCTION SYSTEMS OF BOATHOUSES IN OKI ISLANDS
}

\author{
小林久 高*，釜床 美也子**，安高尚 毅*** \\ Hisataka KOBAYASHI, Miyako KAMATOKO and Naoki ATAKA
}

\begin{abstract}
There are many traditional boathouses called 'Funagoya' in Oki islands. We confirmed the existence situation of Funagoya, and surveyed about arrangement of Funagoya at Iibi village where old village environment is left. Then we investigated wooden construction systems of Funagoya.

As a result, the existence of Funagoya is confirmed at 3 villages newly, and we found out that Funagoya was constructed at 16 villages in old times. We established the type of Funagoya, and made the details of building construction clear.
\end{abstract}

Keywords : Boathouse, Oki islands, Rural landscape, Wooden construction system 舟小屋，隠岐，集落景観，木造建築構法

1. はじめに

\section{1 背景と目的}

日本は海洋に囲まれた水産資源の豊富な国であり、沿岸部におい てはその地域の生業や気候風土に応じて、様々な付属建築物が設け られてきた。漁業や製塩・交易のための作業場・休鄎所・収納庫・ 監視所などが見られるが、本研究で対象とする舟小屋は主に漁業に 用いられる小型の木造舟を収納するための小屋であり、日本海沿岸 地域において多数現存している注1)。かつては半農半漁の自給的な生 活を営む沿岸集落が多く、舟の所有は一般的であり、主な生業が農 業であっても採集的な漁業のための舟を持つことが多かった。また、 移動・運搬の手段としても舟は多用された。

しかし、社会状況の変化により自家の舟による自給的な漁業は不 要となり、漁業は専業的な漁村集落に集約されてきている。また耐 久性の高いF R P 製の舟の出現により舟を保護するための覆い屋を 設ける必要性も減少した。舟による海上交通も利用されなくなり、 かつての沿岸集落が営んできた舟を用いた海辺の生活文化は、舟小 屋の減少と共に忘れ去られようとしている。

本研究においては沿岸部の伝統的集落における特徵的な建築物と して舟小屋を選定し、現存数の多い隠岐諸島においてその分布と建 築構法を確認寸ることによって、建築物と気候風土・生業や地域文 化との関連を考察することを目的とする。

\footnotetext{
* 島根大学大学院総合理工学研究科 准教授・博士 (デザイン学)

** 香川大学工学部安全システム建設工学科 助教・博士 (デザイン学)

*** 小山工業高等専門学校建築学科 准教授·博士 (芸術工学)
}

\section{2 既往研究と本研究の位置づけ}

日本における舟小屋の分布と建築形式の概要については伊藤 ${ }^{2)}$ により報告されており、舟小屋をもつ主な地域の集落構成を比較し た研究 ${ }^{3)}$ も見られる。新潟県においては現存状況に関する詳細な調 查報告 ${ }^{4 ｝{ }^{5)} \text { )があり、立地や外観の類型について整理されている。 }$ しかし島根県においては多数の舟小屋が現存するものの、その分布 状沉や配置形式、建築構法の詳細についての報告は見られない注2)。 そこで、本研究では特に島根県内において舟小屋に関する報告の多 い隠岐諸島を対象とした現地調查を実施し (Table1)、その分布状況 を確認したうえで、建物の立地と建築構法の特性を明らかにする。

\section{3 研究方法}

関連文献注3)により舟小屋の記録を確認したうえで、海辺の全集 落について空中写真注 4 ) により舟小屋の現存状況を推定した。特に 多くの舟小屋の現存が確認された隠岐の島町については、海辺の全 ての集落の悉皆調查を行なった。舟小屋と思われる建物が確認され た海士町、西ノ島町については、主要な集落についての現地調査と 聞き取りを行なった。

特に舟小屋の現存数が多く、集落全体の景観が維持されている隠 岐の島町飯美集落を主な調查対象地として選定し、現存する舟小屋

(Photo1) の実測調查を行なったうえで建設年代、所有関係、利用 法、使用材料、建設手法に関する聞き取りを行なった。
Assoc. Prof., Interdisciplinary Faculty of Science and Engineering, Shimane University, Ph.D. in Design

Research Assoc., Faculty of Engineering, Kagawa University, Ph.D. in Design

Assoc. Prof., Architectural course, National Institute of Technology, Oyama College, Ph.D. in Design 
また、悉皆調査により確認された全舟小屋を対象として基本寸法 の実測を行ない、そのうえで建築類型の整理を行なった。また、主 要な建築物については詳細な実測調査を行なった。

\section{2. 舟小屋の分布状況}

\section{1 地域の概要注 5$)$}

隠岐諸島は島根県の北東沖の約 $50 \mathrm{~km}$ に位置し、島前（西ノ島町、 海士町、知夫村) と島後 (隠岐の島町) の 4 町村で構成される(Fig. 1)。 古くから大陸との海上交通の要衝となっており、18 世紀からは北前 船の寄港地として賑わった。また流人の島としても有名である。 地形：最大の島である隠岐の島町における海岸線の状況を見ると、 北部から西部にかけては強い北西風の影響により海蝕を受けた断崖 が続いている。東部も良港は少ないが、南部から南西部にかけては 良港が見られる。西ノ島町と知夫村は、全島にわたって入り組んだ

Table1 Investigation schedule and contents 表 1 調査日程と調査内容

\begin{tabular}{|c|c|c|c|}
\hline $\begin{array}{l}\text { Date of investigation } \\
\text { [調査日程〕 }\end{array}$ & $\begin{array}{c}\text { Area } \\
\text { [調査集落〕 }\end{array}$ & $\begin{array}{l}\text { Number of } \\
\text { Investigator } \\
\text { [調査員数〕 }\end{array}$ & $\begin{array}{c}\text { Contents of investigation } \\
\text { [調査内容] }\end{array}$ \\
\hline August $19-21,2013$ & $\begin{array}{l}19 \text { Areas in Okinoshima-tyo } \\
\text { [隠岐の島町飯美、都万、他計19集落] }\end{array}$ & 1 & $\begin{array}{l}\text { Confirmation of villages, Hearing } \\
\text { 〔巡検、聞取り) }\end{array}$ \\
\hline August 31-September 1, 2015 & $\begin{array}{l}4 \text { Areas in Okinoshima-tyo } \\
\text { [隠岐の島町布施、都万、飯美、釜] }\end{array}$ & 3 & $\begin{array}{l}\text { Confirmation of villages, Preparation of } \\
\text { investigation [巡検、調查準備〕 }\end{array}$ \\
\hline October 16-18, 2015 & $\begin{array}{l}\text { Okinoshima-tyo Uzuki } \\
\text { [隠岐の島町飯美] }\end{array}$ & 10 & $\begin{array}{l}\text { Arrangement, Measurement, Hearing, Photo } \\
\text { 〔配置、悉皆、実測、聞取り、写真〕 }\end{array}$ \\
\hline March 16-19, 2016 & $\begin{array}{l}27 \text { Areas in Okinoshima-tyo, } 8 \text { Areas in } \\
\text { Ama-tyo, } 5 \text { Areas in nishinoshima-tyo } \\
\text { 〔锾岐の島町27集落、海士町8集落、西 } \\
\text { 島町5集落〕 }\end{array}$ & 1 & $\begin{array}{l}\text { Confirmation of villages, Hearing, } \\
\text { Supplementary survey } \\
\text { [巡検、聞取り、補足] }\end{array}$ \\
\hline September 10-13, 2016 & $\begin{array}{l}7 \text { Areas in Okinoshima-tyo } \\
\text { 〔隠岐の島町伊後、西村、他計7集落〕 }\end{array}$ & 1 & Supplementary survey[補足] \\
\hline
\end{tabular}
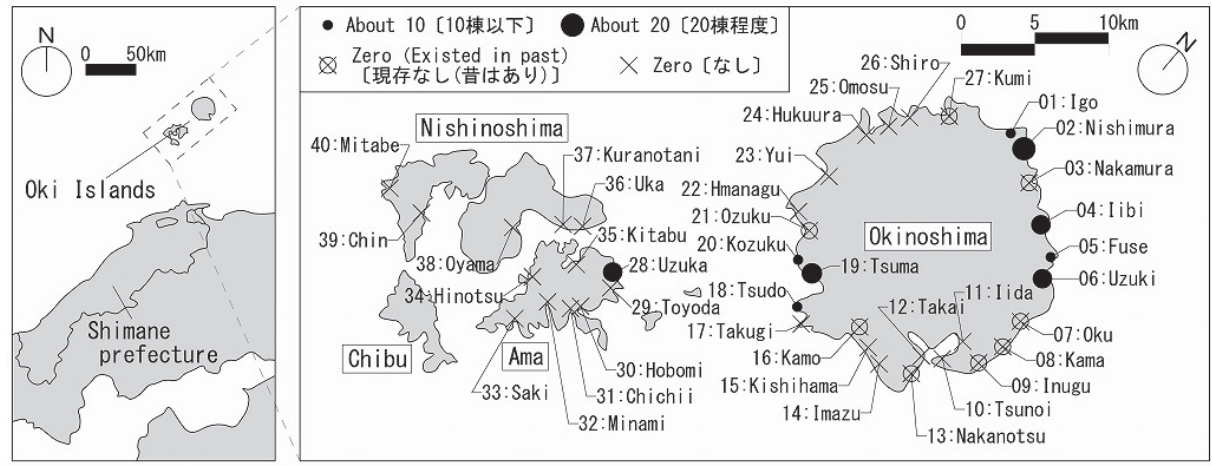

Fig. 1 Existence situation of boathouses

図 1 隠岐諸島における舟小屋の分布状況

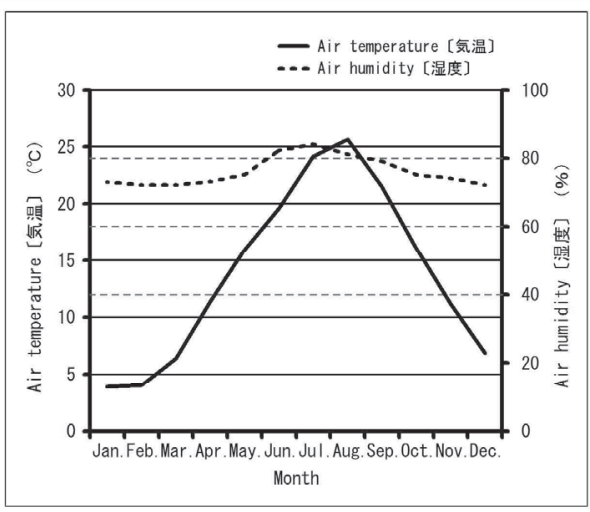

(a) Air temperature and humidity [気温と湿度]

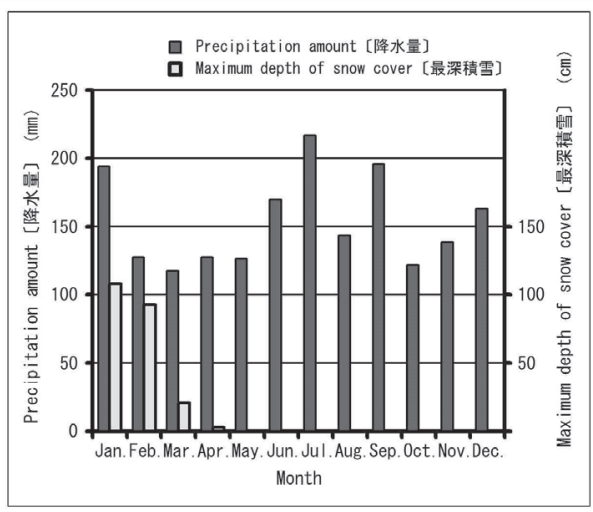

(b) Precipitation amount and Maximum depth of snow cover [降水量と最深積雪量]
断崖絶壁が多い。海士町は、東南部においては断崖の多いリアス式 の海岸だが、西北部の内海に面する部分は平地が多く、水田地帯と なっている。

気候注 6)（Fig. 2）：対馬海流の影響で気温は温暖である。毎月 100 $\mathrm{mm}$ 以上の降雨があるが、特に夏期と冬季に多い。冬季には雪が降る ことがあり、かつては 1 メトル以上の積雪も見られた。年間を通 して北西の風が吹くことが多く、特に冬季には強い北・北西の季節 風が吹き、波も高くなる。

生業：戦前までの主な生業は半農半漁であり、畑作では牧畑注7) が 広く行われていた。近世初めから北前船の寄港地としていくつかの 港が利用され、廻船業も発達した。植林が盛しになると水産加工品 とともに廻船により遠隔地に販売するようになった。

\section{2 各集落における現存数とかつての有無（Fig. 1、Table2）}

ほとんどの舟小屋は島後（隠岐の島町）東部に集中しており、島 前で確認されたのは 1 地域（海士町宇受賀 集落）のみであった。島後で 60 棟（109 区 画注 $\left.^{8)}\right)$ 、島前で 13 棟（20 区画）の舟小屋 を確認した。既往の報告の見られる集落注 9)に加えて、島後においては布施、小津久、 津戸集落において現存を確認し、島前にお いては舟小屋は見られないとされていた が、海士町の宇受賀集落において舟小屋群 を確認した。また、聞取りにより昔の舟小 屋の有無を確認したところ、かつては島後 の東部から南部にかけての 16 集落（現存 は8 集落）において舟小屋が建設されてい たことが確認された。

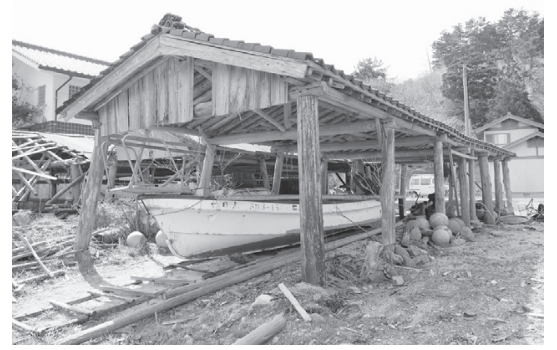

Photo1 Popular type of boathouse "hunagoya" in $0 \mathrm{ki}$ Is lands

\section{写真 1 隠岐諸島における一般的な舟小屋}

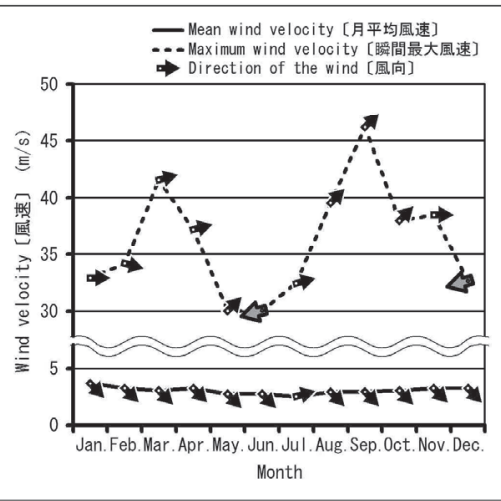

(c) Direction and velocity of the wind [風向と風速の変化]

Fig. 2 Climate of Okinoshima 図 2 隱岐の島の気候条件 


\section{3 舟小屋が設けられる条件}

既往の報告注 10) では日本海沿岸に舟小屋が多ことに着目して、潮 の干満差が小さいこと、冬季の積雪が多いこと、冬季の波浪が厳し く漁ができないことをあげている。隠岐の島町においても同様の条 件が当てはまるが、特に地形の影響が大きく、断崖が多い北西部に おいては舟小屋は建設されていない。文献注 11)により明治初期の生 業と漁船数等を確認寸ると (Table2)、多数の舟小屋が建設された地 域の職業注 12) には農業従事者が多く、地域の概況として一定規模の 田畑を所有していることが多く、産業生産力も高い。農業に加えて 林業や廻船を行なっている地域においても多数の舟小屋が建設され ており、基本的な生活を維持していくための自給自足的な農業や漁 業に加え、広大な田地の所有や、外部との交易を前提とした商業、 工業等が発展し、経済的にある程度の余裕がある地域において建設 されたものと想定される注 ${ }^{13)}$ 。

\section{3. 舟小屋の立地}

\section{1 舟小屋の利用方法}

舟小屋に収納される舟はカンコ舟と呼ばれる小型の木造舟注 14) で
あり、この舟を用いて海岸付近や近海においてカナギ漁注 15$)$ を行な い、また畑の肥料とする藻葉注 ${ }^{16)}$ の採取にも使用された。舟小屋内 部には、舟に加えて漁に用いる道具等が収納される。舟小屋の近く に八デバと呼ばれる作業場を設け、稲やワカメの乾燥作業を行なう ことがある。舟小屋内部においても、ワカメの乾燥や玉ねぎの保存 などが行なわれる。

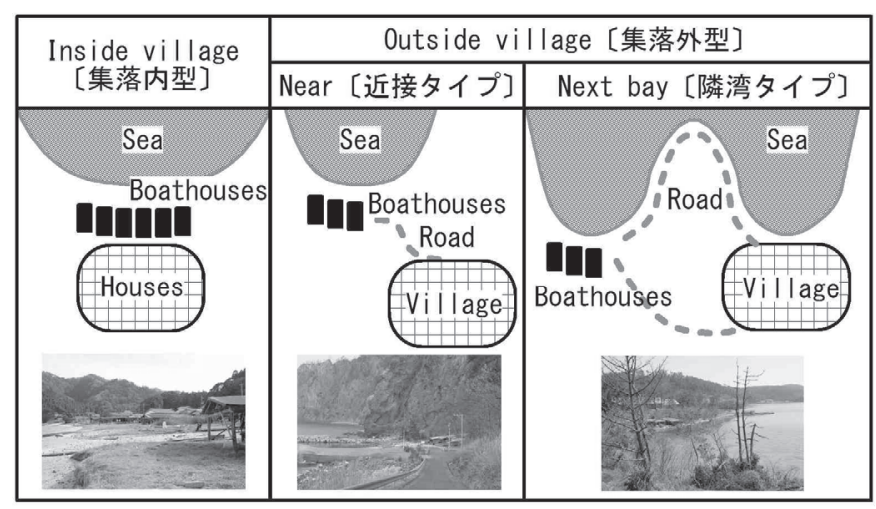

Fig. 3 Type of location 図 3 立地類型

Table2 Situation and number of boathouses at main villages

表 2 各集落における舟小屋数と集落概況

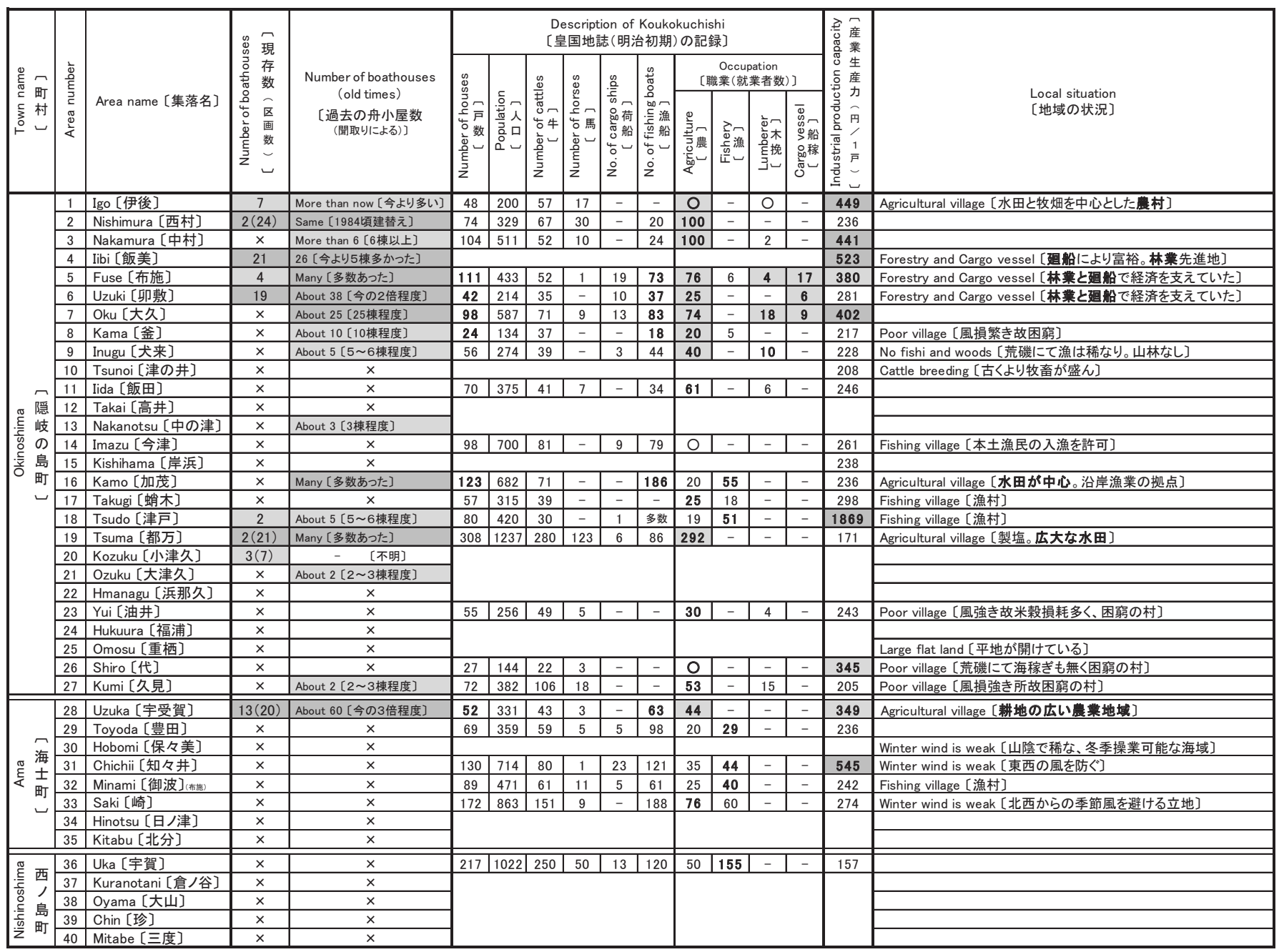

※区画数は、連棟型の舟小屋内部が柱によって区画されている部屋の数と、独立型の舟小屋の数の合計。

※『皇国地誌』(明治初期)の記録については 文献10)の記載を用いた。職業欄の区分について、農: 農業·農漁業・工農業、漁: 漁業·漁農業、船稼: 船稼·船乗、の数值を

集計して記载した。工業、商業の数值は割愛した。空白部分は、記載が無かった集落。

※産業生産カの金額は、文献11)に記載された大正了年頃の数値を用いた。

※産業生産力の金額は、文献11)に記載され 
木造舟は毎日漁が終わると浜に引き上げて保管していた。木造舟 は日に当たると割れが入るため、舟小屋に収納しておくと劣化を防 ぐことができ、60 年程はもつと言われている (宇受賀集落)。荒天時 や冬季の長く出漁しない時期には舟小屋に収納した。舟小屋をもた ない集落では、舟を引き上げておく浜を「フナスエバ (知々井)」「フ ナアゲバ (津戸)」などと呼んでいる。

\section{2 各集落における立地類型 (Fig. 3)}

舟小屋の建設地と居住地域との関係にはいくつかの類型注 ${ }^{17)}$ が見 られ、大きく“集落内型”と“集落外型”に大別できる。集落内型 の 5 集落 [03 中村、04 飯美、05 布施、06 卯敷、19 都万］の多くは 隠岐の島町の東海岸に位置し、多数の舟小屋が浜辺に連立する形式 となっている。これらの集落は河口の三角州に形成されており、集

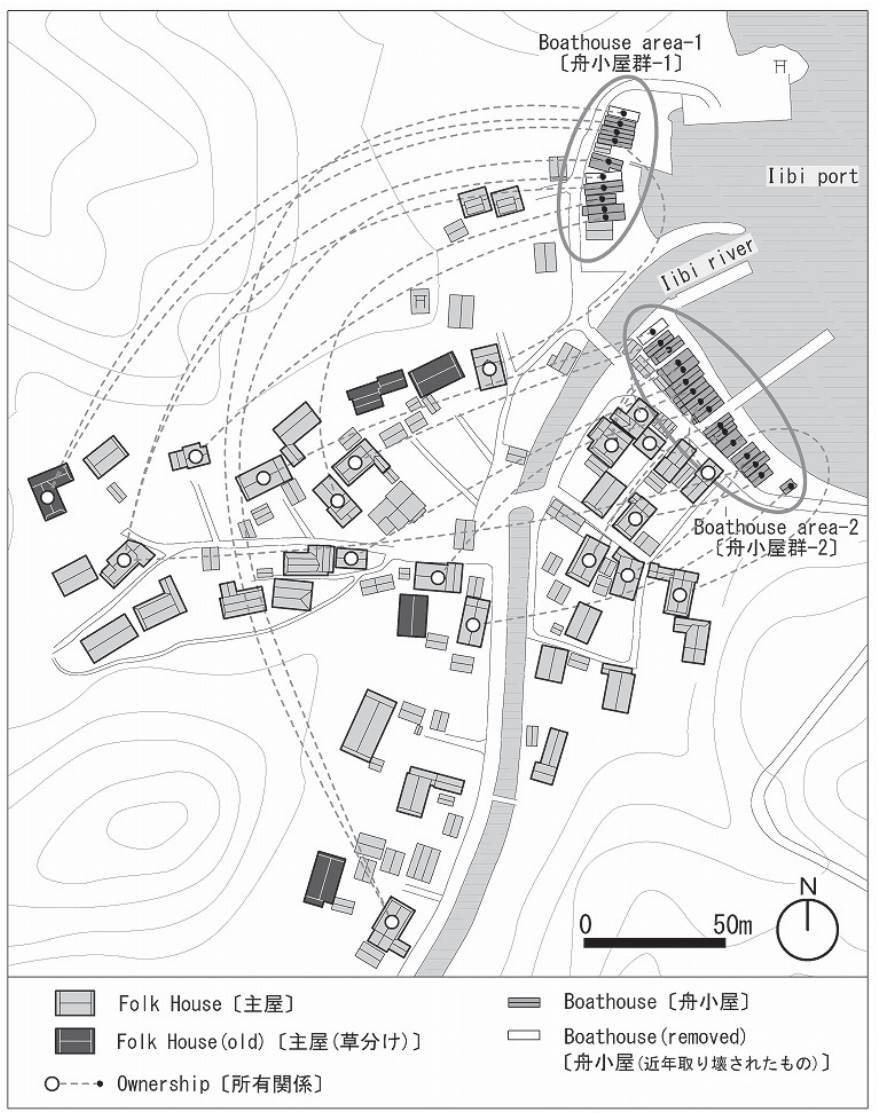

Fig. 4 Location and ownership of boathouses in Iibi 図 4 飯美集落における舟小屋の立地と所有関係

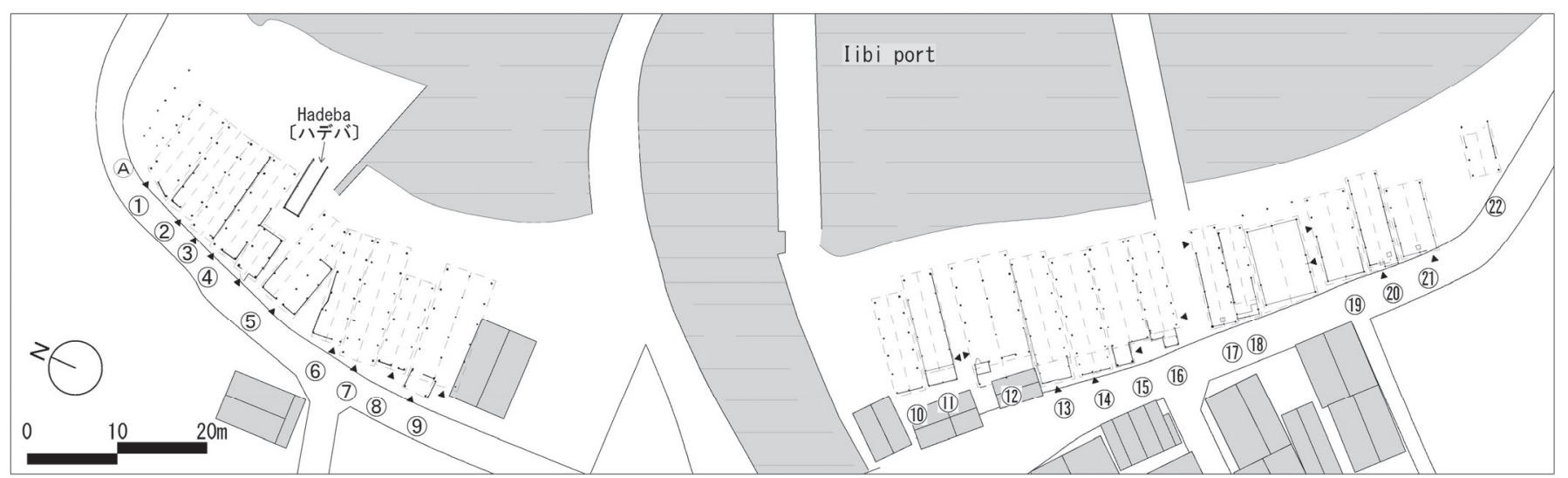

Fig. 5 Plan of boathouses in Iibi

図 5 飯美集落における舟小屋の平面図
落と海岸線は隣接している。舟はある程度の距離を持つ砂浜を経て 舟小屋に収納される。集落外型は更に“近接タイプ” “隣湾タイ プ”に細分類できる。集落外型（近接タイプ）の 4 集落 [01 伊後、 02 西村、13 中ノ津、27 宇受賀］においては、集落は海岸線から離 れた高台に立地し、舟小屋の夕が崖や急傾斜地を隔てた海沿いに設 けられている。集落と舟小屋建設地とは 1 本の細道で繋がっている。 宇受賀集落は海辺に急傾斜地をもたないが、海寄りの平坦地を田地 として利用しており、宅地を谷奥に設けていた。集落外型（隣湾夕 イプ）の 2 集落 [18 津戸、20 小津久］は隠岐の島町西部に位置し ており、集落は “集落内型” と同様に海辺の三角州に立地するもの の、舟小屋は隣の湾に設けられるという特殊な立地となっていた。 聞き取りによると、集落前面の湾は冬に荒れることが多いため、比 較的波の静かな隣の湾で舟を保管していたとのことである。

\section{3 飯美集落における舟小屋の立地}

最も多く見られる集落内型の配置形式について、舟小屋が活用さ れていた頃の集落形態を良く残している飯美集落において現地調查 を行ない、舟小屋の立地状況を記録したうえで所有関係の確認を行 なった。

\section{(1) 立地状況}

立地の概況：飯美集落は、飯美川河口付近の狭小な三角州に形成さ れており、飯美川沿いのエリアと西からの沢筋のエリアに分けるこ

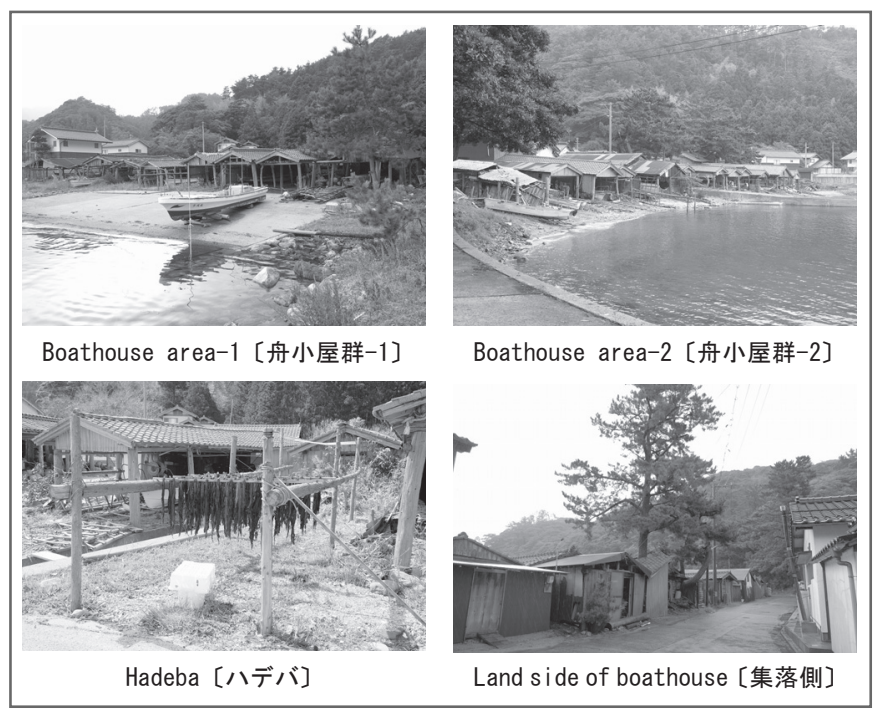

Photo2 Landscape of Iibi 写真 2 飯美集落の景観 
とができる。集落内の地域名は飯美川を挟んで西東に分けられてお り、川の西側を「地組」、東側を「川向組」と呼んでいる。舟小屋の 立地もそれに対応して 2 つの舟小屋群が形成されている (Fig. 4、 Photo 2 上)。平面図 (Fig. 5) により確認すると、岸の曲線に合わ せて建物の配置方向をずらしながら、波打ち際より 5〜10 m 程後退 した位置に建設されるため、普段は潮汐による干満差の影響を受け ることは無い。かつては飯美集落にも帆船があり、海岸線南東に大 きな舟小屋が 3 棟あったものの、大正 8 年の大火で焼失した注 ${ }^{18)}$ 。 作業場である八デバは舟小屋(4)の海寄りに 1 箇所設けられている (Photo 2 左下)。

建物形状と周辺状況：舟小屋はいずれも切妻であり、妻面を海に向 けて櫛比している。海側は壁の無い開放的な構造となっている。集 落側は壁や扉が設けられているものが多く、下屋が増築され漁具置 き場等になっているものが 9 事例あった。海へ通じる小路の両脇で は、側面から出入りするようになっている。隣接する舟小屋間には 壁が設けられないことが多いが、簡易な壁材が設けられている部分 もある。集落側には防風のためのマツが植えられ、さらに道路を挟 んで主屋が建設されている (Photo2 右下)。嘗ては現在よりもマツ が多く、防風林として機能しており、舟小屋も一定の防風効果があ るとされる。しかし、舟小屋は基本的に掘立柱のみで自立しており 横方向の力に対して構造的に弱いため、強風の際には倒壊を避ける ために集落側の壁や扉を開け放ち、風が通り抜けるようにする。

建築年代 : 建築年代が確定できる舟小屋は少ないが、25 年程前に建 替えられたものが多いとされている。飯美集落においては最近の 20 年で半分ほどの舟小屋について補修を行なっている。聞き取りによ り年代が確認できたのは 8 棟（全 22 棟）のみであったが、確認した 最も古い年代は集落に大火があったとされる大正中期であり、最も 新しいものは平成 8 年に建設されていた。

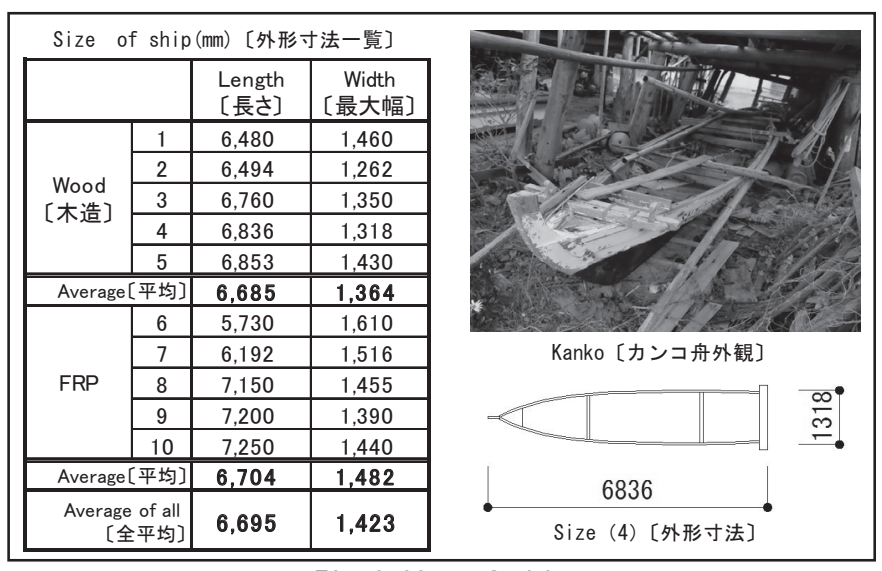

Fig. 6 Size of ship

図 6 木造舟・FRP 舟の外形寸法

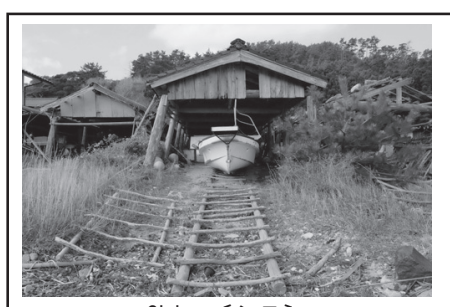

Shira [シラ]

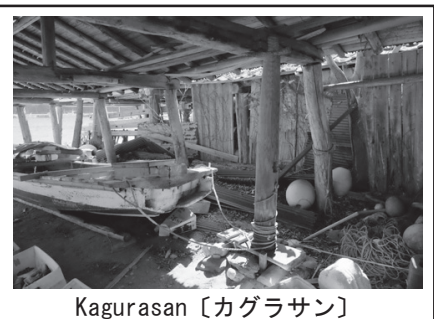

Kagurasan [カグラサン]
Photo3 Method for pulling ship in 写真 3 舟を収納するための装置

\section{(2) 所有関係 (Fig. 4)}

かつては 1 戸あたり 1 棟の舟小屋を所有していたと言われるが、 屋号が確認できる戸数は 42 戸注 ${ }^{19)}$ であり、明治 21 年の統計からは 漁船(小)が 48 艘注 ${ }^{20)}$ とあることから、舟小屋の棟数は舟の数の半 数程度であることがわかる。飯美集落においては舟を 2 艘収納する 「ニハイゴヤ注 21)」が多かったとされており、一定数の舟小屋は共 有で使用し、その他は屋外の船揚場を利用していたと考えられる。 近年では空き家の増加により所有権が譲られ、1 1 戸で $2 \sim 3$ 棟の舟 小屋を所有することもある。飯美集落においては舟小屋の建つ浜は 共有地になっており注 22)、舟小屋本体にのみ所有権がある。

舟小屋の所有関係について、基本的には主屋の位置する東西それ ぞれの浜に所有している。集落の草分けの家が西側に位置している ことから、海抜が比較的高く ( $6 \sim 11 \mathrm{~m}$ 程度 $)$ 、水害を受けにくいと 考えられる西側に集落が形成され始め、舟小屋もそれに対応して北 の小さな岬に囲まれた北西側の浜に立地しているものと考えられる。 家屋の増加により地盤の低い ( $3 \sim 7 \mathrm{~m}$ 程度) 東側に集落が拡大し、 新たな家は東側の浜に舟小屋を建設していったことが想定される。

\section{4. 舟小屋の基本構成と建築類型}

\section{1 舟小屋内の収納物と設備}

舟小屋には、嘗てはカンコと呼ばれる小型木造舟が、現在では同 程度の大きさのF R P 舟が収納されている。実際に収納されている 舟について外形寸法を実測した結果 (Fig. 6)、平均の長さ 6, 695mm、 幅 1, 423mm であり、F R P 舟の幅のほうが $100 \mathrm{~mm}$ 程度広かった。舟 小屋内には棚や小部屋を設けて漁の道具を収納するほか、カナギ漁 に用いられるヤス等の棒状の道具は、梁の上に架け渡すようにして 保管する。内部はワカメの乾燥や玉衩ぎの保管、畑の肥料（藻葉） の保管などにも使用される。

舟を海から引き上げる際には、嘗てはマルタコロとカグラサン (Photo3 右) を用いた。マルタコロとは、舟の両脇に丸太をレール 状に並べ、その上にコロと呼ばれる短めの丸太数本を直角方向にし て舟の下に挟み込んでいくことで転がすように移動させるものであ る。舟に繋いだロープを引き上げるための巻取り機がカグラサンで、

Table3 Type of boathouse 表 3 舟小屋の類型

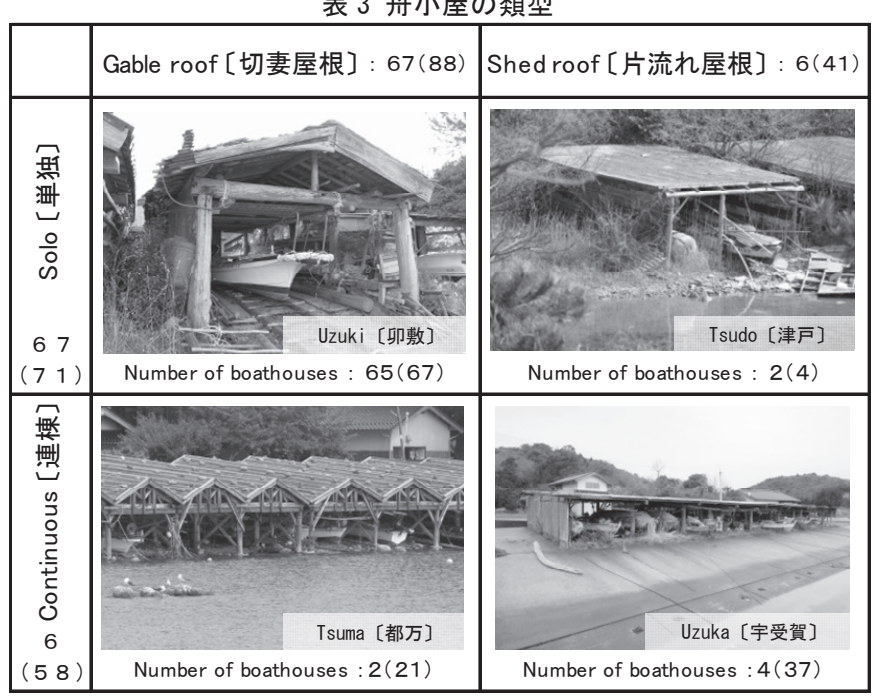

※舟小屋の全棟数は73棟。全区画数は129区画。 ※数值は舟小屋の棟数、()内の数値は区画数。 
舟小屋の奥の梁と地面の間に丸太を回転可能なように縦に設置し、 それを人力で回すことでロープを巻き取っていく。現在ではコロを 固定した形状のシラ (Photo3 左) が多く見られる。

\section{2 舟小屋の類型 (Table3)}

建築形式として、1〜2艘の舟を収納する小型の舟小屋である「単 独型」と、多数の区画を 1 棟の舟小屋の中に設けた大型の「連棟型」 に大別できる。棟数を比較すると、単独型 67 棟、連棟型 6 棟と、単 独型が多数を占めるが、区画数を比較すると単独型 71 区画、連棟型 58 区画となり大差はない。連棟型は、道路拡張や港湾整備等の公共 事業により公的資金を利用して多数の舟小屋を建替えた事例が多い

屋根形状から分類すると、「切妻屋根」と「片流れ屋根（一部招き 屋根)」に2 分される。棟数を比較すると、切妻 67 棟、片流れ 6 棟 となり、切妻屋根が一般的である。連棟型についてはほとんどが片 流れであるが、都万においては観光資源として旧状を復元したため、 連棟型でありながら切妻屋根の形状となっている。

\section{3 舟小屋の基本寸法 ( $\mathrm{Tab} / \mathrm{e} 4)$}

舟小屋が現存する 9 集落のうち、実測が可能な 8 集落の全舟小屋 （71 棟）について基本寸法を採取し、基本構成を確認した。

梁間寸法について、最小寸法は $2,057 \mathrm{~mm}$ 、最大寸法は $6,540 \mathrm{~mm}$ で あり、3000 3500 mm の棟数が 17 棟と最も多く、全体の平均寸法は 3, $560 \mathrm{~mm}$ であった。集落ごとの傾向を見ると、連棟型の舟小屋の見 られる集落において大きくなっている。木造舟の平均的な巾が 1,364mm である (Fig. 6) ことから、梁間 $3,000 \mathrm{~mm}$ 以上の多数の舟小 屋（49 棟、 $75 \%$ ）において 2 艘の舟を収納することが可能であった ことが分かる。桁行寸法については、最少寸法は $3,522 \mathrm{~mm}$ 、最大寸 法は $14,059 \mathrm{~mm}$ と開きが大きく、11,000〜 $11,500 \mathrm{~mm}$ の棟数が 9 棟と 最も多いものの、7, 500〜11, 500 を中心に偏りなく分布している。 全体の平均寸法は 9, $514 \mathrm{~mm}$ となっており、木造舟の平均的な長さが 6, $836 \mathrm{~mm}$ であることから、陸側には $2,500 \mathrm{~mm}$ 程度の空間が確保され ている。特に桁行寸法が大きい飯美集落と卯敷集落においては梁間 寸法が $3,500 \mathrm{~mm}$ 以下のものが多数を占めているが、背後に敷地の余
裕があることから桁行寸法を伸ばすことで収納空間等を確保したも のと考えられる。梁高さは $2,000 \mathrm{~mm}$ 程度が一般的となっているが、 連棟型のものについては $2,200 \mathrm{~mm}$ 程度と高めに設定されている。

桁行方向の柱の本数は桁行寸法と関係しており、桁行寸法の長い 3 集落において 6 本程度の柱を配置している。5 本と6 本を合わせ て 47 棟 ( $72 \%)$ を占めている。桁行方向の柱間隔は最小寸法 $1,654 \mathrm{~mm}$ 、 最大寸法 3, $771 \mathrm{~mm}$ と大きなばらつきがあり、2, 100〜2, $400 \mathrm{~mm}$ (29 棟、 $62 \%$ ）を中心として分布している。全体の平均值は 2, $244 \mathrm{~mm}$ で、そ のうち単独型の平均值は $2,255 \mathrm{~mm}$ (約 7.5 尺）となっており、単独 型の舟小屋において寸法が大きくなる傾向が見られるが、標準寸法 の設定手法については確認することができなかった。

柱太さの最大寸法は、単独型の多い飯美集落・卯敷集落において 特に大きな数值となっている。これは最も海寄りに特に大きな柱を 設けているためで、その他の柱には細い材を用いているものも多い。

壁面の設置割合を見ると、海側には壁は設けられないものの、陸 側や側面を壁で塞いでいる事例も多い。桁行寸法の大きな地域にお いては陸側を塞ぐ傾向があることから、陸側に収納等の空間を設け るために壁を設置したものと考えられる。

\section{5 建築構法の詳細}

\section{1 生産体制}

舟小屋の建設は、集落内の人々が相互扶助の「テマガイ (宇受賀)」 により自力で建設した。使用する木材も自らが山から伐採し準備す る。連棟型のものは公的な資金により大工の手で建設されている。 本章では単独型を中心としてその構法の詳細を述べる。

\section{2 使用木材種 (Photo4)}

使用される木材種に決まりは無く、手に入りや寸く硬い雑木や家 屋等の廃材を用いることが多い。柱材として確認できた木材種は、

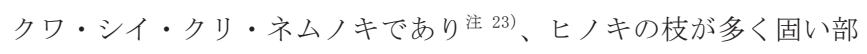
分 (宇受賀)を使用寸ることもあり、適当な材が無い場合にはスギも 使用する (大久)。ネムノキは腐りやすいが加工がしやすく、股木が

Table4 Size and form of boathouses

表 4 各集落の舟小屋における基本寸法の平均値と形式

\begin{tabular}{|c|c|c|c|c|c|c|c|c|c|c|c|c|c|c|c|}
\hline \multirow{2}{*}{ 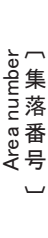 } & \multirow{2}{*}{$\begin{array}{l}\text { Area name } \\
\text { [集落名] }\end{array}$} & \multirow{2}{*}{ 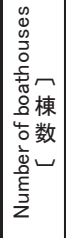 } & \multirow{2}{*}{$\begin{array}{c}\text { Type } \\
{\left[\begin{array}{c}\text { 形式 }] \\
{\left[\begin{array}{c}\text { Solo[単独 }) \\
\text { Continuance } \\
{[\text { 連棟 }]}\end{array}\right]}\end{array}\right.}\end{array}$} & \multicolumn{2}{|c|}{$\begin{array}{l}\text { Length } \\
\text { [平面規模 } \\
\text { (芯々 } \cdot \mathrm{mm} \text { ) }\end{array}$} & \multicolumn{2}{|c|}{$\begin{array}{l}\text { Height } \\
\text { [高さ] }\end{array}$} & \multirow{2}{*}{ 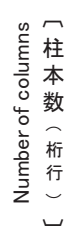 } & \multirow{2}{*}{ 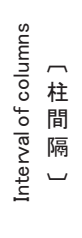 } & \multicolumn{2}{|c|}{$\begin{array}{c}\text { Size of column } \\
\text { [柱太さ〕 }\end{array}$} & \multicolumn{4}{|c|}{$\begin{array}{l}\text { Ratio of wall } \\
\text { [壁面設置割合] }\end{array}$} \\
\hline & & & & $\begin{array}{l}\text { Span } \\
\text { [梁間〕 }\end{array}$ & \begin{tabular}{|c||} 
Ridge \\
direction \\
{$[$ 桁行】 }
\end{tabular} & \begin{tabular}{|l} 
Beam \\
[梁下]
\end{tabular} & $\left.\begin{array}{c}\text { Ridge } \\
\text { pole } \\
\text { [棟木下] }\end{array}\right]$ & & & $\begin{array}{c}\text { Maximu } \\
m \\
\text { [最大] }\end{array}$ & $\begin{array}{c}\text { Average } \\
\text { [平均] }\end{array}$ & \begin{tabular}{|l} 
Sea side \\
[海側]
\end{tabular} & $\begin{array}{c}\text { Land side } \\
\text { [陸側 }]\end{array}$ & $\left.\mid \begin{array}{c}\text { Right side } \\
{[\text { 右側 }} \\
\text { (海から) }\end{array}\right]$ & $\begin{array}{l}\text { Left side } \\
\text { 〔左側 } \\
\text { (海から) }\end{array}$ \\
\hline 1 & Igo[伊後] & 7 & Solo (7) & 2,646 & 6,643 & 1,602 & 2,198 & 4.0 & 2,234 & 141 & 134 & 0.03 & 0.00 & 0.31 & 0.27 \\
\hline 2 & Nishimura [西村] & 2 & Continuance (2) 25blocks & 4,422 & 6,783 & 2,218 & 2,776 & 4.5 & 2,031 & 118 & 118 & 0.00 & 0.00 & 1.00 & 1.00 \\
\hline 4 & Iibi〔飯美〕 & 22 & Solo (22) & 3,562 & 11,015 & 1,989 & 2,753 & 5.8 & 2,306 & 214 & 164 & 0.00 & 0.72 & 0.36 & 0.31 \\
\hline 5 & Fuse [布施] & 4 & Solo(4) & 3,428 & 7,885 & 1,934 & 2,567 & 4.8 & 2,144 & 190 & 153 & 0.00 & 0.70 & 0.61 & 0.55 \\
\hline 6 & Uzuki [卯敷] & 20 & Solo (20) & 3,449 & 10,018 & 1,773 & 2,503 & 5.3 & 2,195 & 221 & 170 & 0.03 & 0.37 & 0.23 & 0.25 \\
\hline 19 & Tsuma [都万] & 2 & Continuance (2) 21 blocks & 5,002 & 7,974 & 1,958 & 3,182 & 5.0 & 1,994 & 180 & 180 & 0.00 & 0.50 & 1.00 & 1.00 \\
\hline 20 & Kozuku [小津久] & 2 & $\begin{array}{l}\text { Continuance (1) 5blocks } \\
\text { Solo (1) }\end{array}$ & 4,261 & 6,548 & 2,296 & 1,467 & 3.0 & 3,274 & 175 & 155 & 0.00 & 0.00 & 0.00 & 0.00 \\
\hline 28 & Uzuka［宇受賀] & 13 & $\begin{array}{l}\text { Continuance (1) 8blocks } \\
\text { Solo(12) }\end{array}$ & 3,932 & 9,388 & 2,162 & 2,744 & 5.7 & 2,122 & 167 & 154 & 0.00 & 0.40 & 0.57 & 0.42 \\
\hline \multicolumn{4}{|c|}{ Average of all [全平均] } & 3,560 & 9,514 & 1,939 & 2,627 & 5.3 & 2,244 & 193 & 158 & 0.01 & 0.45 & 0.40 & 0.35 \\
\hline
\end{tabular}

※数值は、各集落における全舟小屋の平均值 (または平均数)とする。

※平面規模は舟小屋本体部分のみを対象とし、後から付加された下屋部分等は含まない。

※連棟型の舟小屋の平面規模については、1区画の寸法を用いた。 
多いため良い(飯美) とされる。スギを用いる際には掘立柱の地中 部分を火で焼いて炭化させることで腐りにくくする (都万)。近年の 事例ではクリの電信柱を再利用した柱も見られる。梁材にはマツが 用いられることが多いが、スギも用いられる。

\section{3 共通する基本構成}

単独型の舟小屋の基本的な形式は、切妻造りの妻入りで壁面をも たない開放的なもので、柱・梁、屋根、壁による単純な構成である。

柱・梁: 柱は柱脚部を $70 \mathrm{~cm} \sim 1 \mathrm{~m}$ ほど地中に埋めた掘立て柱となっ ている。西村集落における 2 棟は布基礎を用いているが、他は全て 掘立て柱（柱脚をコンクリートで補強したものを含む）であった。 柱は垂直には建てられず、梁間方向の上部間隔が狭くなるように、 内転びに設置されることが多い。こうすることにより強風時にも倒 れにくいとされている。柱の断面形状は、丸柱が 62 棟、角柱は 4 棟 で（うち 2 棟は連棟型、1 棟はコンクリート柱）、殆どが丸柱であっ た。梁に使用されるのもほとんどが丸太材であり、角材の使用は 8 棟（うち 4 棟は連棟型）のみであることから、比較的近年になって から行政主体により建設された連棟型において、角材が使用される 割合が高いことが確認された。架構は、一部の連棟型のもの以外は 全て柱の上に梁材をかけて桁材で連結する折置き組みとなっている

(Fig. 8（1）断面図）。柱頭部と梁材の仕口には様々な加工法が見 られる(Photo6)。最も古いとされるのは叉木の利用で小屋束にも使 用される。ホゾには、丸ホゾ・角ホゾ・平ホゾが確認され、突き付 けのうえカスガイのみで固定しているものも見られた。梁の断面形 状は、丸が 58 棟、角は 8 棟であり、丸太材の利用が多い。

屋根：屋根仕上げ材は、昭和 30 年代までは杉皮莫きの石置き屋根 (Photo5 、Fig. 7) が多く見られたが、現在では卯敷集落の 1 棟を 残すのみとなった。屋根仕上げ材の割合は、トタン波板 (30 棟、48\%)、 セメント瓦 (18 棟、29\%)、波型スレート（6棟、10\%)、瓦（4 棟、 $6 \%) 、$ 鉄板（4棟、6\%) であった。

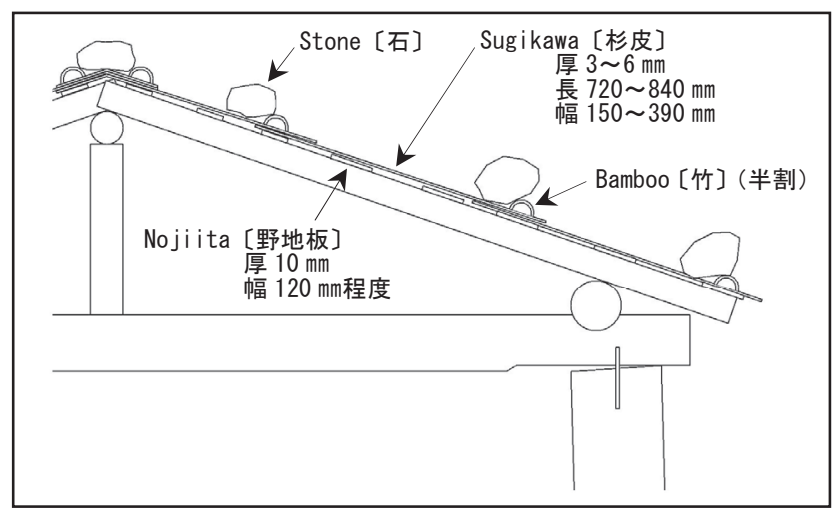

Fig. 7 Construction of Sugikawa-buki roof 図 7 石置き屋根の構成

壁：壁材の割合は、木製の板（25 件、52\%）、トタン波板（13 棟、 $27 \%)$ 、板 ・ トタンの混用 $(8$ 棟、 $17 \%)$ 、鉄板 $(1$ 棟、 $2 \%$ )、杉皮

（1棟、2\%）であった。強風時には風が抜けるようにするため陸 側の壁を開放するが、撤去しやすいように戸板を利用した壁も多い。 海側には基本的に壁を設けないが、小屋組みの妻面部分にのみ壁を 設けたものが 27 棟存在した。特に事例の多い飯美集落（17 棟）で は雨除けの為に設けているとのことで、強風による倒壊を避けるた めに妻面の一部に敢えて風抜きの穴を設けたものが 6 事例見られた。 5.4 代表的な舟小屋の実例

主な事例について、実測調査を基に建築構法の詳細を確認する。 昔からの形式で事例数の多い 単独・切妻型を 3 事例（標準的なも の・屋根面の設定が異なるもの・2 艘の舟を収納するもの)、近年に なって建設された 連棟・切妻型、連棟・片流れ（招き）型をそれぞ れ 1 事例選定した注 24$)$

（1）飯美集落の一般的な舟小屋（Fig. 8 左上、Table4 集落番号 4 参照

隠岐において最も多く確認された形式の舟小屋。丸太柱を掘立で 設置し、梁を折置きに架けている。使用材は、垂木以外は全て丸太 材である。柱と梁の仕口は角ホゾとなっており、部分的にカスガイ で補強されている(Photo6)。梁の中央に小屋束を建てて棟木を支え る。屋根面は地盤の傾斜に沿うようにして設けられるが、海側の梁 高さが若干高めに設定されている。現状の屋根莫き材はセメント瓦 であるが、嘗ては杉皮莫きであった。柱には電柱の再利用材と曲り のある広葉樹が混用されている。

（2）宇受賀集落の屋根面の設定が水平な舟小屋（Fig. 8 左中、 Table4 集落番号 28 参照)

基本構成は (1) と同様であるが、屋根面を水平に設けることで、 海側の開口が高くなっている。このような構造は「素人による自力 建設であるため」と言われるが、理由は不明である。柱には節の多 いヒノキ材が多用されているが、傷みが激しく、添え柱が設けられ ている。使用されている材は、垂木を含めてほぼ全てが丸太材であ る。柱と梁の仕口には丸ホゾと平ホゾが用いられており（Photo6）、

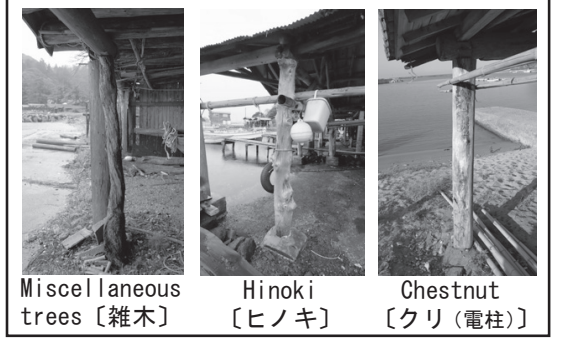

Photo4 Type of column 写真 4 柱の木材種

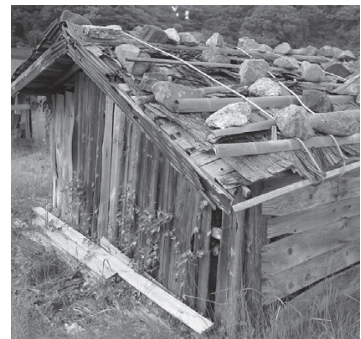

Photo5 Roof with stones 写真 5 石置き屋根

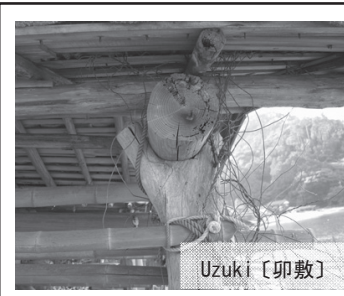

Matagi〔叉木〕

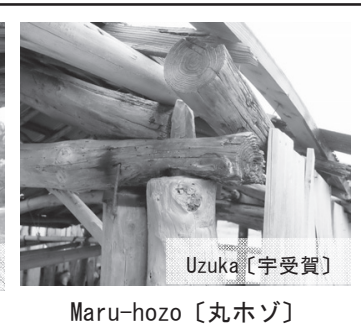

Maru-hozo[丸ホゾ]

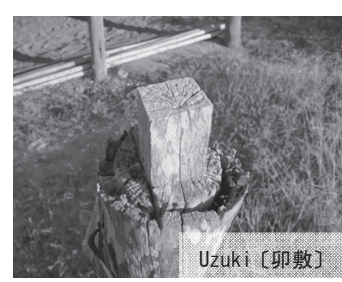

Kaku-hozo[角ホゾ]

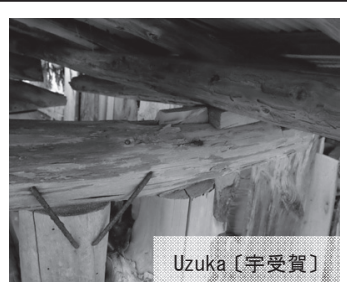

Hira-hozo[平ホゾ]

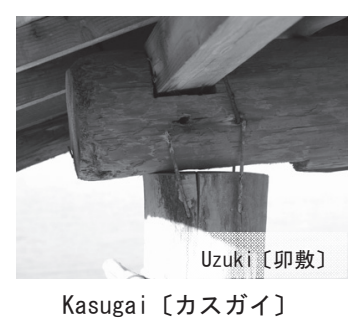

Kasugai〔カスガイ〕

Photo6 Type of joints 写真 6 柱頭に使用される仕口 


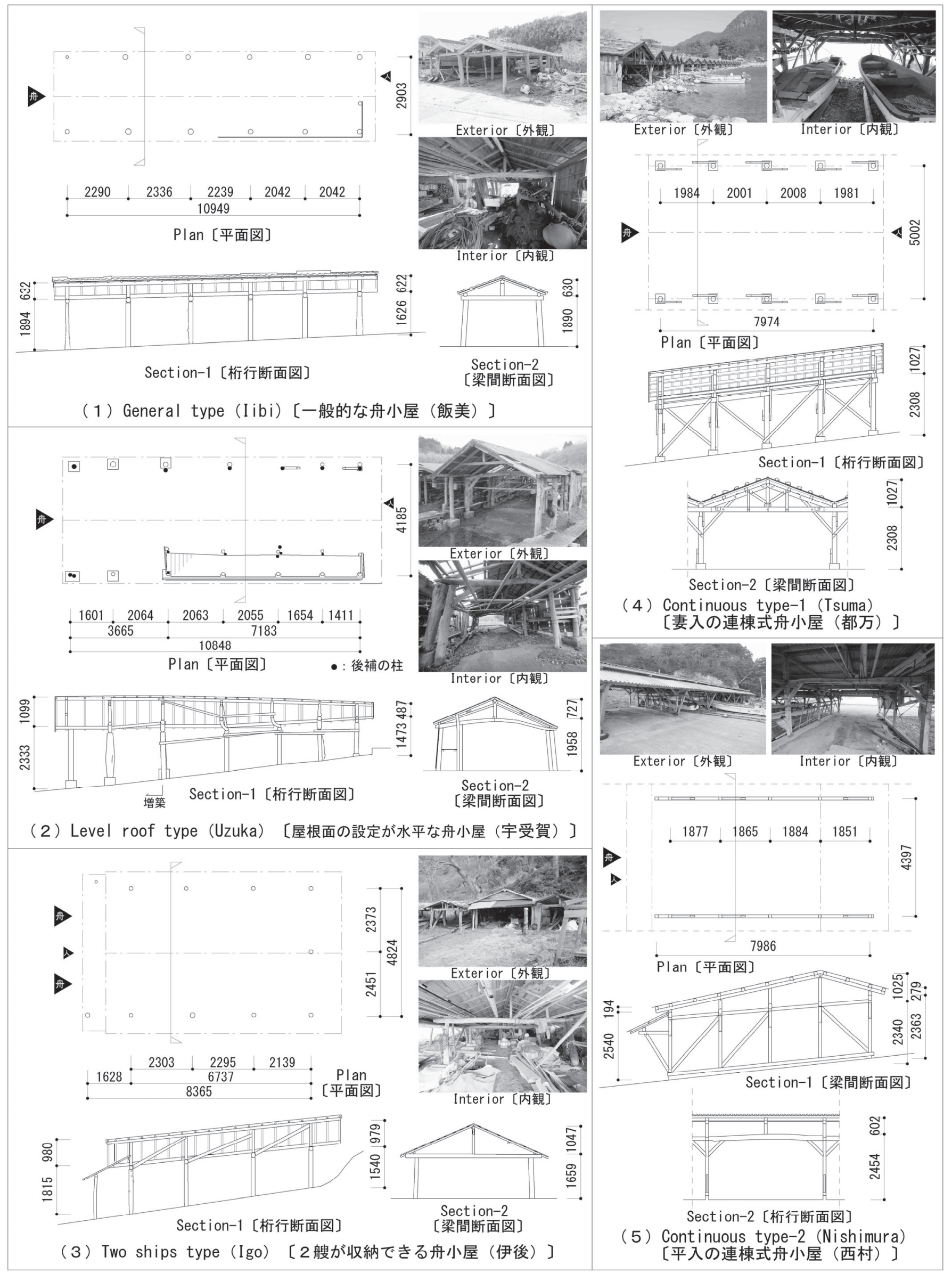

Fig. 8 Drawing of typical boathouses 図 8 代表的な舟小屋の実測図面 
添え柱はカスガイにより固定されている。陸側の梁が低くなってい るが、曲り梁を用いることで室中央部の高さを確保している。梁間 寸法が比較的大きく、内部側面には漁具を収納するための棚が設け られている。小屋束には叉木が用いられており、その両脇には登り 梁が設けられる。現状の屋根莫き材はトタンとなっている。道路拡 張により陸側の約 2 間分が解体されてしまったため、海側に増築し ている。

\section{( 3 ) 伊後集落の 2 艘が収納できるニソウゴヤ (Fig. 8 左下、Table4 集落番号 1 参照)}

2 艘の舟を 1 棟に収納できるように梁間の設定を大きくした舟小 屋。基本的な構成は（1）と同様である。他地域では梁間の中間部 分に柱を建てた形式も見られる。海側に庇を設けている点が特徽的 であり、屋根莫き材はトタン波板となっている。垂木以外の柱や梁 などのほぼすべての部材が丸太によって構成されているが、仕口の 形状は確認できなかった。後方に崖が迫っているため、桁行寸法は 比較的短い。

\section{（4）都万集落の切妻屋根の連棟式舟小屋（Fig. 8 右上、Table4 集 落番号 19 参照)}

1987 年の道路拡張工事に伴って既存の舟小屋を撤去し、場所を移 して公共事業として大工により新築したもの。以前は単独・切妻の 舟小屋が建ち並んでいたが、連棟式に変更され、かつての雾囲気を 再現するために妻面を見せる形式としている。柱は掘立とし、足元 をコンクリートで補強している。外部から見える柱については伝統 的な形式である丸柱を使用しているが、梁等のその他の部材につい ては全て角材を使用している。5区画のものと 16 区画のものの 2 棟 が建設されている。仕口の詳細は不明であるが、構造にはトラス・ 方杖を多用し、ボルトやカスガイ等の金物を多用寸ることで補強し ている。各区画に 2 艘の舟を収納する。屋根莫き材としてかつての 形式である石置き屋根を再現している。

\section{（５）西村集落の片流れ屋根の連棟式舟小屋（Fig. 8 右下、Table4 集落番号 2 参照))}

1984 年に建替えられたもので、連棟・片流れ（招き）形式となっ ており、8 区画と 17 区画の 2 棟が建設されている。公共事業として 大工により建設され、舟小屋には珍しく土台を用いた在来工法の構 造であり、部材の固定にはカスガイが多用されている。柱は $115 \mathrm{~mm}$ の角柱が用いられるなど、小屋組みを含めた構造材はほとんどが正 角材であるが、梁には太鼓梁を使用している。柱は屋根面直下の登 り梁を支持しており、梁・桁は柱横面にホゾ差しのうえ短冊金物や カスガイで固定されている。連投形式の舟小屋（都万以外）は、こ れと類似した構造となっている。屋根莫き材は波型スレートとして いる。

\section{6. まとめ}

本研究においては隠岐諸島を対象とし、舟小屋の分布と配置、建 築構法の詳細を調查した。

分布については、既存の報告の見られない舟小屋について報告す ると同時に、かつての舟小屋の分布状況を確認し、気候風土や集落 の生業との関連による考察を加えることで、崖地が少なく、自給自 足的な農業・漁業を行なっていながら生産性が高い地域、または商 業や工業等が発展し、比較的経済に余裕のある地域において多数の
舟小屋が建設されてきたことを明らかにした。

また、全集落における舟小屋の立地状況を確認し、3 類型に整理 した。さらに代表的な集落景観をもつ飯美集落において配置の詳細 を確認したうえで利用法や防風効果に関する検証を行い、舟小屋の 所有関係についても明らかにした。

舟小屋の類型については、単独型と連棟型に大別したうえで切妻 屋根と片流れ屋根に細分類した。また、全舟小屋の基本寸法を比較 検討することで、各類型や地域ごとの傾向を示した。さらに実測調 查に基づいて、代表的な事例の建築構法の詳細について確認した。

現在では舟小屋が使用されることは少なく、舟小屋をもつ海辺の 集落景観は失われようとしている。しかし、舟小屋は地域の歴史や 生活を伝える文化財として貴重な存在であり、また観光資源として の価值も認められることから、今後は保存・活用を進めていくこと が望まれる。今回調查を実施した隠岐諸島及び出雲地域においては、 切妻屋根・単独型で丸太材を多用した平屋建ての舟小屋が建ち並ぶ 集落景観が見られ主 25)、また隠岐諸島においては杉皮莫きの石置き 屋根が使用されていた点が特徵となっている。舟小屋は日本海沿岸 の広範な地域に多数現存しており、多様な配置形式や建築構法が確 認されている。今後は他地域の事例との詳細な比較検討を行なうこ とにより地域的な特性を明らかにしていきたい。

\section{参考文献}

1) Kanzaki, N. et al. : Hunagoya Huudo to Katachi, INAX, 2007 (in Japanese)

神崎宣武, 中村茂樹, 畔柳昭雄, 渡邊裕之: 舟小屋 風土とかたち(INAX BOOKLET)， INAX 出版, 2007

2) Ito, M. et al. : A Study on the Living Space Characteristic on Ship Huts on Coastal Zone of Sea of Japan, Summaries of Technical Papers of Annual Meeting, Architectural Institute of Japan, Architectural Planning and Design-2, pp. 421-422, 1999. 7 (in Japanese) 伊藤昌明, 岡野崇裕, 畔柳昭雄 : 日本海沿岸に立地する舟小屋の空間特 性に関する調査・研究, 日本建築学会大会学術講演梗概集, E-2, pp. 421-422, 1999.7

3) Okano, T. Kuroyanagi, A. and Nakamura, S. : A Study on Living Space Characteristic of Fishing Villages with Boathouses on Coastal Zone Where is Raine ane Snowy, Journal of Architecture, Planning and Environmental Engineering (Transactions AIJ), No.526, pp. 131-138, 1999. 12 (in Japanese)

岡野崇裕, 畔柳昭雄, 中村茂樹：沿海多雨・多雪地域に立地寸る舟小屋 を有する集落の生活空間特性に関する研究, 日本建築学会計画系論文集 526, pp. 131-138, 1999. 12

4) Shibamine, T. and Imamura, Y. : Remaining Condition and Appearance Character of Ship Huts in Niigata Prefecture, Proceedings of Annual Meeting of Hokuriku Chapter (AIJ) 54, pp. 409-412, 2011. 7 (in Japanese) 柴嶺高行, 今村洋一：新潟県における舟小屋の残存状況及び外観特性, 日本建築学会北陸支部研究報告集 54, pp. 409-412, 2011.7

5) Umibe no Koya Niigata no Hunagoya $\cdot$ Hamagoya $\cdot$ Banya, Kashiwazaki Furusato Jinbutsukan, 2008 (in Japanese) 海辺の小屋 新潟の舟小屋・浜小屋・番屋, 柏崎ふるさと人物館, 2008

6) Asakawa, S. : Oki no Juukyo to Hunagoya, Nihon no Bijutsu 406 Ritou no Kenchiku, pp. 42-55, Shibun-Dou, 2000 (in Japanese) 浅川滋男：隠岐の住居と舟小屋，日本の美術406離島の建築，pp. 42-55, 至文堂, 2000

7) Matsuura, Y. : Mede miru Okino 100-nen, Kyoudo-Syuppan, 1999 (in Japanese)

松浦康麿：目で見る隠岐の 100 年, 郷土出版社, 1999

8) Oki Konjaku Shashintyou, Kyoudo-Syuppan, 2007 (in Japanese) 隠岐今昔写真帖, 郷土出版社, 2007

9) Nagami, K. : Oki no Minzoku, Imai-Shoten, 1969 (in Japanese) 永海一正：隠岐の民俗, 今井書店, 1969

10) Edited by Takeuchi, R. : Kadokawa Geographical Name Dictionary 32 Shimane Prefecture, Kadokawa-Shoten, 1979 (in Japanese) 
竹内理三編：角川地名大辞典 32 島根県, 角川書店, 1979

11) Shimane Prefectural Department of Interior: Shimane-ken gyogyou kihon-chousa houkoku, 1914 (in Japanese) 島根縣漁業基本調查報告 水面利用調査 其一，島根縣内務部， 1914

12) Shimane Prefectural Board of Education: Okinosima no Minzoku, Shimane Prefectural Board of Education, 1973 (in Japanese) 島根県教育委員会：隠岐島の民俗，島根県教育委員会，1973

13) Editorial Committee of Saigoutyou: Hurusato Arubamu Saigou, Public office of Saigoutyou, 1989 (in Japanese)

西郷町合併三十周年記念写真集編纂委員会編 : ふるさとアルバム西郷, 西郷町, 1989

14) Editorial Committee of Tsuma-sonshi: Tsuma-sonshi, Public office of Tsumamura, 1990 (in Japanese)

都万村誌編纂委員会：都万村誌，都万村， 1990

15) Editorial Committee of Huse-sonshi: Huse-sonshi, Public office of Husemura, 1986 (in Japanese) 布施村誌編さん委員会：布施村誌，布施村， 1986

16) Edited by Abe, M. : Goka-sonshi, Public office of Gokamura, 1989 (in Japanese)

安部勝編：五箇村誌，五箇村役場， 1989

17) Nagami, K: Kuroki-sonshi, Editorial Committee of Kuroki-sonshi, 1968 (in Japanese) 永海一正： 黒木村誌，黒木村誌編集委員会，1968

注

注 1）文献 1 によると、ほぼすべての舟小屋が日本海沿岸に立地している。 それ以外の地域における記録としては、伊豆諸島に関する記録が見ら れるほか、青森県下北半島北東部、四国北西部において現存が確認さ れている。

注 2) 文献 6 において、都万・卯敷の舟小屋の実測図が紹介され、中村・西 村に舟小屋が現存することが紹介されている。

注 3) 各町村誌等に加えて、地域の写真集である文献 7 、文献 8 により舟小 屋の記録を確認した。

注 4）空中写真は Google マップによる。撮影日は 2012 年 11 月である。

注 5）文献 9 、文献 10 による。

注 6）文献 16, p. 13 西郷測候所資料による。最多風向については昭和 36 年 (1961) から昭和 55 年 (1980) までの記録。その他は、昭和 14 年 (1939) から昭和 62 年（1987）までの記録、に基づいて図を作成し分析する。

注 7）農耕と牧畜を兼ねた営農形態で、山野を利用して烟作と放牧を土地を 移動しながら順次行っていく

注 8） 1 棟の舟小屋の内部を区切って利用しているものについては、室の数 を「区画」として集計した。1 区画に 2 艘の舟を収納することもある。

注 9）文献 1 、文献 6 において、都万、卯敷、飯美、伊後、大津久、中村、 西村の舟小屋が報告されている。今回の調査で確認したところ、大津 久、中村の舟小屋は現存しなかった。

注 10）文献 1 , pp. 34-39 による。

注 11）文献 10 記載の『皇国地誌』（明治初期）に基づいた数值を抜粋した。

注 12）生業は、半農半漁であることが多く、畜産、山樵との兼業も多い。本 稿では主な生業を分析の対象に用いる。

注 13）文献 14 , p. 863 においては、「古くから本村の各浦には港あるいはそれ に類する船揚場はあったが、構築物や防波堤などの施設の備わってい る所はほとんどなく、大半の浦では浜辺に小船を引き上げておく程度 で、船小屋を持つのは良い方であった。とされており、都万村におい ては経済的に余裕のある集落において舟小屋が建設されていたことが わかる。

注 14）文献 14, p. 851、文献 17, p. 407 によると、内海で利用する木造の漁 船は主に 3 種あり、(1)テヤス : 5 枚板舟で、巾 6 尺、長さ 6 尋程度。 イカ釣り、その他の漁撈で使用。近世から一般的。(2)カンコ : 5 枚板 舟で、巾 $4 \sim 6$ 尺、長さ 4 尋 2 尺〜 5 尋 4 尺。主にカナギ漁で使用。軽 快で機動性に優れる。(3) トモド : 栉舟で、巾 3 尺、長さ約 3 間半。カ ナギに使用。波摇れが少なく安定、である。カナギ漁においてかつて はトモドが用いられていたが、次第にカンコが用いられるようになっ ていき、現在はF R P 製の舟が使用されている。

注 15）文献 13, p. 46 によると、沿岸でアワビやサザエ、タコなどを獲る漁。 箱メガネと数種のヤスを操って漁をする。

注 16) 文献 12 , p. 85 によると、タカモ、ジンバやアラメなどで、主に麦、 桑畑や田の肥料とした。

注 17）文献 3 では、舟小屋が集落に隣接している集落内型と、集落外に建設 される集落外型に大別し、集落外型を集約型と分散型に細分類してい る。隠岐の島においては分散型が見られないため、別の分類を用いる。
注 18）文献 15, p. 487 飯美集落では昭和の初期ごろまで迴船が行われてい たため、時化の際には大型帆船が多数入港し、集落の東外れの現在は 護岸がされているあたりに停泊していたという。

注 19）文献 15 , p. 552 による。

注 20）文献 15, p. 27 による。

注 21） 2 艘の舟を収納できる舟小屋を「ニソウゴヤ（都万）」「ニハイゴヤ (飯美)」などとよぶ。1 艘収納のものは「イッソウゴヤ（都万）」「イ ッパイゴヤ（飯美）」である。

注 22）飯美においては役所が所有する土地を共同で使用しているが、大久で は舟小屋の土地は個人で所有していたとのことである。土地の所有形 式には集落ごとに違いが見られる。

注 23）文献 1 , p. 44 によると、卯敷集落では現地名称が「アツカベ」とい う常緑針葉樹で、一般的には「鼠子 (ネズコ)」「黒檜（クロベ）」と呼 ばれる材を使用するとしている。

注 24）残る類型の、単独・片流れ型は津戸集落の 2 事例であるが、事例数が 少ないこと、舟小屋に至る道が整備されておらず近づけないこと、建 設年が 1995 年頃と比較的新しく構法的な特徵が少なそうであること から、実測調査は実施しなかった。

注 25）単独型の舟小屋が多数（10 棟以上）建ち並ぶ集落景観を現在見ること のできる集落は、隠岐諸島においては 飯美・卯敷・宇受賀、出雲地域 においては 松江市野波、出雲市多伎町小田である。他地域においても 舟小屋が建ち並ぶ景観は散見される（鳥取県岩美町東浜、兵庫県香美 町安木、京都府伊根町新井・平田、福井県小浜市田烏谷及 等）が、構 造としては四周に壁・扉を設けたものが多数で、かつ大型化または 2 階建てとなっているものも多い。

※本研究は科学研究費補助金（基盤研究（C））「舟小屋等の環日本海の伝 統的民家における文化伝播の検証」（課題番号：15K06359）、および日本 海学研究グループ支援事業助成金により行なった。 


\title{
A STUDY ON EXISTENCE SITUATION AND WOODEN CONSTRUCTION SYSTEMS OF BOATHOUSES IN OKI ISLANDS
}

\author{
Hisataka KOBAYASHI*, Miyako KAMATOKO ** and Naoki ATAKA*** \\ * Assoc. Prof., Interdisciplinary Faculty of Science and Engineering, Shimane University, Ph.D. in Design \\ ** Research Assoc., Faculty of Engineering, Kagawa University, Ph.D. in Design \\ *** Assoc. Prof., Architectural course, National Institute of Technology, Oyama College, Ph.D. in Design
}

Japan is a country surrounded by seas and has abundant marine resources. Therefore, there are various hut for fishery along coast. Boathouse "Funagoya" is one of them, and is a hut to put a small wooden ship inside. There are a lot of boathouses in Oki Islands. A purpose of this study is to confirm the present conditions of the boathouse in Oki Islands.

At first, we confirmed the distribution of boathouses. Then, we performed hearing investigation about the placement and made a survey of representative boathouses. Thereafter, we considered about relationship between boathouse and climate, occupations and local culture.

We found new boathouses in 3 villages, and confirmed that there were boathouses in old days in 16 villages. There are few boathouses in northwest area of Okinoshima-cho, where we can see many cliffs. And, it became clear that there are many boathouses in areas rich economically in old days.

We classified location of the boathouse into 3 types. Then, we checked placement and the possession relations of boathouses in Iibi village having representative landscape. We confirmed that boathouses protect wind from sea. And it was revealed that the tendency of the owner is different from the east side of the Iibi River in the west.

We classified the form of the boathouse into 4 types. And we showed the difference of type and constructional element, by comparing all boathouses. Continuous type boathouses have long span in beam direction, and solo type boathouses have long span in ridge direction. The length 1-ken of solo type is bigger than continuous type. In areas where the length of ridge direction is big, they make walls to village side and make space for storage.

Villagers built boathouses by themself. They made boathouses with miscellaneous small trees and scrap woods of houses. Pillar of boathouse was buried in the ground, roof was made with the peel of cedar. We investigated five representative boathouses, and clarified the details of the building method of boathouses. Solo type boathouses are made with many logs. Continuous type boathouses are made with square timbers and joint metals. Most of continuous type boathouses are new and are built by public fund. And one of them is made with traditional method of "Zairai-kouhou" using ground sill.

Almost all boathouses are not in use now, and seaside landscape with boathouses is disappearing. But, boathouses are local precious cultural resources, and have high value as tourist attractions. It will be important to preserve and utilize them. 